\title{
Impact of leptin gene polymorphisms on breeding value for milk production traits in cattle*
}

\author{
J. Komisarek ${ }^{1,1}$, J. Szyda ${ }^{2}$, A. Michalak ${ }^{1}$ and Z. Dorynek ${ }^{1}$ \\ ${ }^{I}$ The August Cieszkowski Agricultural University of Poznań, \\ Department of Cattle Breeding \\ Wojska Polskiego 71 A, 60-625 Poznań, Poland \\ ${ }^{2}$ Agricultural University of Wroctaw, Department of Animal Genetics \\ Kożuchowska 7, 51-631 Wroctaw, Poland
}

(Received 1 July 2004; revised version 21 March 2005; accepted 4 August 2005)

\begin{abstract}
The aim of the study was to analyse the relationship between the Arg4Cys and Ala59Val polymorphisms of the bovine leptin gene, and the milk traits, based on the breeding values of AI proven bulls. A total of 187 individuals was analysed. The following allele frequencies have been found: $0.55(\mathrm{C})$ and $0.45(\mathrm{~T})$ for Arg4Cys, and $0.73(\mathrm{C})$ and $0.27(\mathrm{~T})$ for Ala59Val. Arg4Cys TT genotype has a highly significant increasing effect on milk yield and a significant increasing effect on protein yield, whereas no marked influence of this polymorphism can be observed on butterfat yield. Consequently, the content of butterfat is highly significantly decreased by genotype TT. In contrast, Ala59Val does not affect amounts of milk and protein, but is responsible for controlling the amount of produced butterfat.
\end{abstract}

KEY WORDS: cattle, breeding value, leptin gene, milk traits, polymorphism

\section{INTRODUCTION}

Feed intake is an important factor affecting animal productivity. The consequences of inadequate nutrition include inhibited growth and reproductive function,

\footnotetext{
${ }^{*}$ Supported by the State Committee for Scientific Research, Grant No. 2 P06D 01726

${ }^{3}$ Corresponding author: e-mail: komisjol@jay.au.poznan.pl
} 
lowered resistance to diseases, and reduced milk production. In dairy cattle, feed intake varies considerably during the production cycle. During pregnancy, it is generally in excess of energy needs, then decreases by about one-third in a week before parturition, and gradually increases after calving. At the early lactation, feed intake is not sufficient to satisfy metabolic demands of animals. It is a period of negative energy balance, when a substantial proportion of milk production is achieved by the mobilization of body fat reserves (de Vries and Veerkamp, 2000).

Leptin, a $16-\mathrm{kDa}$ protein hormone produced and secreted mainly by a white adipose tissue, is one of the factors involved both in the feeding behaviour and in fat mobilization. It has been shown to play a key role in the regulation of the whole body energy homeostasis. Additionally, it influences reproduction, as well as immune and stress responses, hormone secretion by several endocrine glands, haematopoiesis, angiogenesis, and bone formation (Houseknecht et al., 1998; Fruhbeck, 2001). Many of leptin effects are mediated centrally, at the level of the hypothalamus. The hormone stimulates or inhibits the release of neurotransmitters such as neuropeptide $\mathrm{Y}$ that ultimately results in the reduction of feed intake and an increase of energy expenditure. Multiple peripheral effects were also described (Houseknecht et al., 1998). The widespread expression of the leptin Ob-Rb receptor observed in cattle suggests that the hormone may act directly in most bovine tissues (Silva et al., 2002). In the mammary gland, it has been shown to decrease the DNA synthesis and reduce the proliferation of epithelial cells. Hence, leptin is thought to be involved in mechanisms regulating the mammary growth and development (Silva et al., 2002).

Leptin is a product of the obese $(o b)$ gene (Zhang et al., 1994). The precursor form of the protein consists of 167 amino acids and contains an amino-terminal secretory signal sequence that affects the translocation of polypeptide into microsomes. The signal sequence is subsequently cleaved off resulting in the active form of hormone consisting of 146 amino acids (Zhang et al., 1994). In cattle, the leptin gene has been mapped to chromosome 4 (Pomp et al., 1997). It consists of three exons, with the coding regions in exon 2 and exon 3 . Several polymorphims have been reported in the bovine leptin gene, but only four of them change the amino acid sequence in the encoding polypeptide (Konfortov et al., 1999; Haegeman et al., 2000; Buchanan et al., 2002; Lagonigro et al., 2003; Liefers et al., 2003). Recently, the promoter region has been sequenced and twenty SNPs (single nucleotide polymorphisms) have been found (Liefers, 2004).

The aim of the present study was to analyse the relationship between the Arg4Cys and Ala59Val polymorphisms of the bovine leptin gene, and the milk traits, based on the breeding values of genotyped AI proven bulls. The Arg4Cys is the $\mathrm{C} \rightarrow \mathrm{T}$ substitution located $73 \mathrm{bp}$ from the start of exon 2 that causes amino 
acid change from arginine to cysteine at position 4 of the mature leptin (Konfortov et al., 1999; Buchanan et al., 2002; Lagonigro et al., 2003; Liefers et al., 2003), whereas the Ala59Val is the $\mathrm{C} \rightarrow \mathrm{T}$ mutation located $95 \mathrm{bp}$ from the start of exon 3 leading to the alanine $\rightarrow$ valine change at protein position 59 (Konfortov et al., 1999; Haegeman et al., 2000; Buchanan et al., 2002; Lagonigro et al., 2003; Liefers et al., 2003).

\section{MATERIAL AND METHODS}

\section{Data}

The study included 187 Black-and-White AI bulls with an average HolsteinFriesian genes share of 96.4\%, born between 1992 and 1998. Their genetic background is represented by breeding values (EBV) estimated on the national scale for milk, butterfat and protein yields as well as butterfat and protein contents using a multiple trait animal model in the November 2003 evaluation (Źarnecki et al., 2003). The variability of EBVs among sampled bulls amount to $293 \mathrm{~kg}$ milk, $12.1 \mathrm{~kg}$ fat, $8.1 \mathrm{~kg}$ protein, $0.24 \%$ fat and $0.11 \%$ protein. Reliabilities of EBVs are expressed by the number of daughters, with the average being 288 daughters per bull varying between 12 and 6668 .

\section{Molecular data analysis}

Genome DNA was isolated from semen as described by Lucy et al. (1993). Primers for PCR amplification (IBB PAS, Poland) were designed using the Primer3 program (http://www.genome.wi.mit.edu/cgi-bin/primer/primer3_www.cgi) on the basis of the gene sequence available in the GenBank, accession number U50365:

Arg4Cys - F: 5' - CCAGGGAGTGCCTTTCATTA - 3'

Arg4Cys - R: 5' - GGTGTCATCCTGGACCTTC ${ }^{*} \mathrm{C}-3$ ',

Ala59Val - F: 5' - AGCTTGGAAACATGGTGGTC - 3'

Ala59Val - R: 5' - TTTCTGGAAGGCAGACTC ${ }^{*} \mathrm{GT}$ - 3'

The Arg4Cys and Ala59Val reverse primer sequences included a purposeful mismatch (marked with an asterisk) that incorporated a Kpn2I and HphI restriction sites, respectively.

The PCR amplifications were performed in a reaction volume of $25 \mu \mathrm{l}$ containing approximately $50 \mathrm{ng}$ of genomic DNA, 1 unit of Taq DNA polymerase (Fermentas), $1 \times$ PCR buffer with $\left(\mathrm{NH}_{4}\right)_{2} \mathrm{SO}_{4}$ (Fermentas), $2 \mathrm{mM} \mathrm{MgCl}, 5 \%$ DMSO, $1 \mu \mathrm{M}$ of each primer, and $200 \mu \mathrm{M}$ of each dNTP. Thermal cycling conditions included an initial denaturation at $94^{\circ} \mathrm{C}$ for $5 \mathrm{~min}$, followed by 30 
cycles of $94^{\circ} \mathrm{C}$ for $30 \mathrm{~s}, 56.5^{\circ} \mathrm{C}$ (Arg4Cys) or $57.5^{\circ} \mathrm{C}$ (Ala59Val) for $30 \mathrm{~s}$, and $72^{\circ} \mathrm{C}$ for $30 \mathrm{~s}$, followed by the final extension at $72^{\circ} \mathrm{C}$ for $5 \mathrm{~min}$. The PCR reactions were carried out using a TGradient thermocycler (Biometra).

The amplified fragments ( $5 \mu \mathrm{l}$ of PCR products) were digested with 8 units of restriction endonucleases (Fermentas) at $55^{\circ} \mathrm{C}$ (Arg4Cys - Kpn $\left.2 \mathrm{I}\right)$ or $37^{\circ} \mathrm{C}$ (Ala59Val - HphI) for at least $2.5 \mathrm{~h}$. The resulting products were visualized in 3\% agarose gels stained with ethidium bromide.

\section{Statistical analysis}

The estimation of the effects of Arg4Cys and Ala59Val polymorphisms on milk production traits is based on the following model:

$$
\mathbf{y}=\mathbf{X} \boldsymbol{\beta}+\mathbf{Z} \boldsymbol{\alpha}+\mathbf{e}
$$

where $\mathbf{y}$ is a vector of EBVs for one of the five milk production traits considered, standardized to have variance equal to 1 and the zero mean; $\beta$ is a vector of fixed effects comprising the general mean and the Arg4Cys and Ala59Val genotypes; $\alpha$ is a vector of random polygenic effects assuming $\boldsymbol{\alpha} \sim \mathrm{N}\left(0, \mathbf{A} \sigma_{\alpha}^{2}\right)$ with $\mathbf{A}$ representing additive relationships among individuals and $\sigma_{\alpha}^{2}$ being a component of the total additive genetic variance attributed to polygenes; $\mathbf{e}$ is a vector of random errors assuming $\mathbf{e} \sim \mathrm{N}\left(0, \mathbf{D} \sigma_{e}^{2}\right)$ with $\mathbf{D}$ being a diagonal matrix with the reciprocal of the number of daughters used for the calculation of EBV for the i-th bull and $\sigma_{e}^{2}$ denoting the error variance; $\mathbf{X}$ and $\mathbf{Z}$ are corresponding design matrices.

Although the estimation of Arg4Cys and Ala59Val genotype effects are of the primary interest for the study, a random effect accounting for (dis)similarities among bulls on the genome average level, as represented by $\alpha$, is also included into the model. Similar approach has already been used e.g. by Grisart et al. (2002) for testing effect of the DGAT1 polymorphism on milk yield and composition and by Blott et al. (2003) in the analysis of growth hormone receptor variants influence on the same traits.

The parameters underlying the above model (i.e. $\beta$ and $\alpha$ ) were estimated with maximum likelihood method using the SAS software (SAS, 1999); additionally a package PEDIG (Boichard, 2002) was used to construct the numerator relationship matrix. It should be noted, that only the models' effects were estimated while, due to the small size of the analysed sample, the variance components were assumed as known, based on the upper values of genetic parameters used for the national genetic evaluation (Żarnecki et al., 2003), amounting to $\sigma_{\alpha}^{2}=0.30, \sigma_{\mathrm{e}}^{2}=0.70$. 


\section{RESULTS}

The PCR reactions resulted in $305 \mathrm{bp}$ long products for both analysed leptin gene polymorphisms. After the Arg4Cys fragment digestion with the restriction enzyme Kpn2I, the arginine encoding allele (C) was cleaved into two fragments of $283 \mathrm{bp}$ and $22 \mathrm{bp}$, while a cysteine encoding allele (T) remained uncut at 305 bp. The Ala59Val variants were identified with the $H p h \mathrm{I}$ restriction endonuclease. The alanine (C) allele was visible in gel as a single band of $305 \mathrm{bp}$, whereas the valine (T) allele had fragments of 276 and $29 \mathrm{bp}$.

Within the population examined, the Arg4Cys-CC genotype was identified in 50, CT in 101, and TT in 33 animals, which gives the $\mathrm{C}$ and $\mathrm{T}$ allele frequencies of 0.55 and 0.45 , respectively. For the Ala59Val polymorphism, the following genotype and allele frequencies were obtained: CC - 0.53, CT - 0.40, and TT $-0.07 ; \mathrm{C}-0.73$, and $\mathrm{T}-0.27$, respectively. Since the polygenic effect was the only random effect in the model, the correlations between the original EBVs and the EBVs represented by $\hat{\alpha}$ are very high amounting to 0.97 for fat yield and content, 0.98 for milk and protein yields and 0.99 for protein content. For the two polymorphisms studied, Table 1 summarises the effects of a homozygous and a heterozygous genotype estimated as a contrast to the other homozygote. The significance of the effects is expressed by the type I error rate corresponding to a comparison of the estimated genotype effect with null using a standard t-test. Summarising, Arg4Cys allele T has a highly significant increasing effect on milk yield (animals with TT genotype produce $155.74 \mathrm{~kg}$ more milk on average than animals with CC genotype) and a significant increasing effect on protein yield (3.2422 $\mathrm{kg}$ more protein), whereas no marked influence of this

TABLE 1

Estimated genotype effects and their significance $\left({ }^{*} \mathrm{P} \leq 0.05,{ }^{*} \mathrm{P} \leq 0.01,{ }^{*} * \mathrm{P} \leq 0.001\right.$, ns - not significant) of Arg4Cys and Ala59Val. Genotype effects are expressed in contrast to the homozygous genotypes CC and TT respectively for Arg4Cys and Ala59Val

\begin{tabular}{lccccc}
\hline \multirow{2}{*}{ Indices } & \multicolumn{2}{c}{ Arg4Cys } & & \multicolumn{2}{c}{ Ala59Val } \\
\cline { 2 - 3 } \cline { 5 - 6 } \cline { 5 - 6 } Milk yield, $\mathrm{kg}$ & $\mathrm{TT}$ & $\mathrm{CT}$ & & $\mathrm{CC}$ & $\mathrm{CT}$ \\
& 155.74 & 60.93 & & -37.58 & 58.92 \\
Fat yield, $\mathrm{kg}$ & $* *$ & $\mathrm{~ns}$ & & $\mathrm{~ns}$ & $\mathrm{~ns}$ \\
& -1.4060 & 0.4187 & & 6.2609 & 7.5006 \\
Fat content, $\%$ & $\mathrm{~ns}$ & $\mathrm{~ns}$ & & $* *$ & $* * *$ \\
& -0.1560 & -0.0547 & & 0.1729 & 0.1287 \\
Protein yield, $\mathrm{kg}$ & $* * *$ & $*$ & & $* * *$ & $* *$ \\
& 3.2422 & 1.0288 & & -1.3468 & 1.3515 \\
\multirow{2}{*}{ Protein content, $\%$} & $*$ & $\mathrm{~ns}$ & & $\mathrm{~ns}$ & $\mathrm{~ns}$ \\
& -0.0400 & -0.0223 & & 0.0080 & -0.0037 \\
& $\mathrm{~ns}$ & $\mathrm{~ns}$ & & $\mathrm{~ns}$ & $\mathrm{~ns}$ \\
\hline
\end{tabular}


polymorphism can be observed on butterfat yield. Consequently, the content of fat in milk is highly significantly decreased by allele $\mathrm{T}$ (TT genotype contain by 0.156 $\%$ less butterfat on average than CC genotype). In contrast, Ala59Val does not affect the amounts of milk and protein, but is responsible for controlling the amount of produced butterfat (on average, CC produce $6.2609 \mathrm{~kg}$ and CT $7.5006 \mathrm{~kg}$ more fat than TT). It should be noted, that while the estimated genotypic effects of Arg4Cys reveal additive mode of inheritance, Ala59Val seems to be overdominant.

\section{DISCUSSION}

The effects of the leptin gene variants on the phenotype were first observed in mice. The $o b / o b$ mice lacking functional hormone are characterized by hyperphagia, decreased energy expenditure and extreme obesity, as well as many other abnormalities including infertility, decreased body temperature, and decreased immune function (Hamann and Matthaei, 1996). The physiological properties, as well as the effects of the mouse $o b$ locus variants support leptin as a strong candidate gene that could influence production traits in farm animals. In cattle, several studies have indicated an association between leptin gene polymorphisms and feed intake and carcass fat content, although reproduction and milk related traits were proved to be also affected (Fitzsimmons et al., 1998; Zwierzchowski et al., 2001; Liefers et al., 2002, 2003).

Buchanan et al. (2002) proposed the C/T substitution in exon 2 that causes amino acid change from Arg to Cys at position 4 of the leptin protein (Arg4Cys) as a causative mutation affecting fat carcass content in cattle. They sequenced the $o b$ gene from six animals belonging to a population, in which the associations between the BM1500 microsatellite located $3.6 \mathrm{~kb}$ downstream the leptin stop codon (Stone et al., 1996) and fat carcass traits were previously reported (Fitzsimmons et al., 1998). Three of them were characterized by a fat phenotype, three others represented the lean phenotype. Two SNPs changing the leptin protein amino acid sequence were identified (Arg4Cys and Ala59Val), but only Arg4Cys genotypes were different between the sequenced fat and lean bulls. The results obtained by Buchanan et al. (2002) indicate that the T (cysteine encoding) allele is associated with higher, whereas the $\mathrm{C}$ (arginine encoding) variant with lower fat deposition in carcasses of Angus, Charolais, Hereford and Simmental bulls. Moreover, the TT homozygotes were found to produce more leptin mRNA than the CC animals.

The Arg4Cys polymorphism was also shown to be associated with milk related traits in the Canadian Holstein cows population (Buchanan et al., 2003). The T allele increased milk yield, protein yield and somatic cell count, and slightly reduced the milk butterfat content. The most significant effects were observed in the first 100 
days of lactation. Over the entire lactation, the impact of Arg4Cys SNP revealed to be significant for milk yield and somatic cell count, and approached significance for milk protein yield. The results of the present study were very similar to those obtained by Buchanan et al. (2003). The Arg4Cys polymorphism influenced milk and protein yields as well as butterfat percentage, but its impact on the latest trait seems to be greater than in the Canadian Holsteins. Since the phenotypes analysed in this study were bulls' breeding values evaluated on their daughters 305-day lactation basis, it was impossible to estimate the mutation effects at the different stages of lactation.

An Arg to Cys amino acid change is situated in the A-helix of the leptin protein at position that varies considerably between species (Zhang et. al., 1997). However, it is a non-conservative substitution, as arginine and cysteine have an alkaline and neutral side chains, respectively. According to Buchanan et al. (2002), the cysteine encoding $\mathrm{T}$ allele is associated with increased leptin mRNA expression. They hypothesized that the extra unpaired cysteine presence in the leptin molecule might affect the tertiary structure of the protein and decrease its activity. Thus, the TT homozygotes would produce hormone largely unrecognised by its receptor. That would results in the silencing of the downregulation of the leptin expression, and in increasing the serum leptin level. Another consequence of the lesser cysteine variant activity in these animals could be a higher feed intake, leading to an increased fat carcass content, and, in lactating dairy cows, to an earlier recovery from the negative energy balance and greater milk production.

The above hypothesis is to a large extent consistent with the Arg4Cys polymorphism effects obtained in the present study. However, it does not fully explain the decreased breeding value for milk butterfat content in the TT genotype bulls. The reduced butterfat percent in bovine milk is considered as an indicator of energy deficits during early lactation (de Vries and Veerkamp, 2000). Hence, if the $T$ allele improved the energy utilization, it should not be associated with the lower milk fat content. On the other hand, the observed negative effect on fat percentage could be simply a consequence of the higher milk yield without simultaneously increased amount of produced fat. The investigations on Dutch heifers (Liefers et al., 2003; Liefers, 2004) and British experimental population (Lagonigro et al., 2003) provided more arguments against the hypothesis postulated by Buchanan et al. (2002). Liefers et al. (2003) obtained results suggesting that not the TT, but the CC genotype is characterized by a higher circulating leptin concentration. Moreover, there are reports that no relation exists between the Arg4Cys mutation and both milk (Liefers, 2004; Madeja et al., 2004) and carcass (Lagonigro et al., 2003) traits in cattle.

The Ala59Val polymorphism, caused by the $\mathrm{C} / \mathrm{T}$ replacement in exon 3 of the gene, is located at between species conserved leptin protein region. However, since 
both alanine and valine belong to the same group of the non-polar aliphatic amino acids, the substitution is unlikely to alter the hormone functioning. For this reason, it did not receive a lot of attention. In the present study we found that Ala59Val could be responsible for the amount of produced fat and consequently also on milk fat content. The results of Madeja et al. (2004), on the other hand, showed that polymorphism has a significant effect on milk and protein yields. Fat yield also tended to be affected, but, in contrast to the present study, animals with TT genotype had a higher EBV for this trait. Liefers et al. (2002) suggested that Ala59Val might be a marker for the butterfat percentage in milk, although they formulated their conclusion very cautiously. The same authors showed that polymorphism significantly influences the Holstein heifers' serum leptin concentrations during pregnancy (Liefers et al., 2003). However, similar results were obtained for three other mutations, including Arg4Cys. Since the analysed polymorphisms were in linkage disequilibrium, the found association could be the effect of the Arg4Cys SNP as well. The impact of Ala59Val mutation on feed intake and fat-related carcass traits in beef cattle was evaluated by Lagonigro et al. (2003), but no significant relationship has been identified.

\section{CONCLUSIONS}

In conclusion, the Arg4Cys - TT genotype appears to be associated with increased milk and protein yields being neutral to butterfat yield, while the Ala59Val - CC seems to increase milk fat production. Because of the putative effect on the leptin molecule conformation, the Arg4Cys is more likely to be a causative mutation affecting the milk-related traits in cattle. Further experiments, however, are necessary to provide unambiguous evidence that both analysed polymorphisms lead to changes in the leptin function.

\section{REFERENCES}

Blott S., Kim J.-J., Moisio S., Schmidt-Küntzel A., Cornet A., Berzi P., Cambisano N., Ford C., Grisart B., Johnson D., Karim L., Simon P., Snell R., Spelman R., Wong J., Vilkki J., Georges M., Farnir F., Coppieters W., 2003. Molecular dissection of a quantitative trait locus: A phenylalanine-totyrosine substitution in the transmembrane domain of the bovine growth hormone receptor is associated with major effect on milk yield and composition. Genetics 163, 253-266

Boichard D., 2002. Pedig: a Fortran package for pedigree analysis suited for large populations. Proceedings of the 7th World Congress: Genetic Applied Livestock Production CD-ROM Communication No. 28-13

Buchanan F.C., Fitzsimmons C.J., Van Kessel A.G., Thue T.D., Winkelman-Sim D.C., Schmutz S.M., 2002. Association of a missense mutation in the bovine leptin gene with carcass fat content and leptin mRNA levels. Genet. Sel. Evol. 34, 105-116 
Buchanan F.C., Van Kessel A.G., Waldner C., Christensen D.A., Laarveld B., Schmutz S.M., 2003. An association between a leptin single nucleotide polymorphism and milk and protein yield. J. Dairy Sci. 86, 3164-3166

de Vries M.J., Veerkamp R.F., 2000. Energy balance of dairy cattle in relation to milk production variables and fertility. J. Dairy Sci. 83, 62-69

Fitzsimmons C.J., Schmutz S.M., Bergen R.D., McKinnon J.J., 1998. A potential association between the BM 1500 microsatellite and fat deposition in beef cattle. Mamm. Genome 9, 432-434

Fruhbeck G., 2001. A heliocentric view of leptin. Proc. Nutr. Soc. 60, 301-318

Grisart B., Coppieters W., Farnir F., Karim L., Ford C., Berzi P., Cambisano N., Mni M., Reid S., Simon P., Spelman R., Georges M., Snell R., 2002. Positional candidate cloning of a QTL in dairy cattle: Identification of a missense mutation in the bovine DGAT1 gene with major effect on milk yield and composition. Genome Res. 12, 222-231

Haegeman A., van Zeveren A., Peelman L.J., 2000. New mutation in exon 2 of the bovine leptin gene. Anim. Genet. 31, 79

Hamann A., Matthaei S., 1996. Regulation of energy balance by leptin. Exp. Clin. Endocrinol. Diabetes 104, 293-300

Houseknecht K.L., Baile C.A., Matteri R.L., Spurlock M.E., 1998. The biology of leptin: A review. J. Anim Sci. 76, 1405-1420

Konfortov B.A., Licence V.E., Miller J.R., 1999. Re-sequencing of DNA from a diverse panel of cattle reveals a high level of polymorphism in both intron and exon. Mamm. Genome 10, 1142-1145

Lagonigro R., Wiener P., Pilla F., Woolliams J.A., Williams J.L., 2003. A new mutation in the coding region of the bovine leptin gene associated with feed intake. Anim. Genet. 34, 371-374

Liefers S.C., 2004. Physiology and genetics of leptin in periparturient dairy cows. PhD. Thesis, Wageningen University, Wageningen (The Netherlands)

Liefers S.C., te Pas M.F.W., Veerkamp R.F., Chilliard Y., Delavaud C., Gerritsen R, van der Lende T., 2003. Association of leptin gene polymorphisms with serum leptin concentration in dairy cows. Mamm. Genome 14, 657-663

Liefers S.C., te Pas M.F.W., Veerkamp R.F., van der Lende T., 2002. Associations between leptin gene polymorphisms and production, live weight, energy balance, feed intake, and fertility in Holstein heifers. J. Dairy Sci. 85, 1633-1638

Lucy M.C., Hauser S.D., Eppard P.J., Krivi G.G., Clark K.J., Bauman D.E., Collier R.J., 1993. Variants of somatotropin in cattle: Gene frequencies in major dairy breeds and associated milk production. Domest. Anim. Endocrinol. 10, 325-333

Madeja Z., Adamowicz T., Chmurzyńska A., Jankowski T., Melonek J., Świtoński M., Strabel T., 2004. Effect of leptin gene polymorphisms on breeding value for milk production traits. J. Dairy Sci. 87, 3925 - 3927

Pomp D., Zou T., Clutter A.C., Barendse W., 1997. Mapping of leptin to bovine chromosome 4 by linkage analysis of a PCR-based polymorphism. J. Anim. Sci. 75, 1427

SAS, 1999. SAS/STAT User's Guide, Version $8^{\text {th }}$, SAS Inst., Inc., Cary, NC

Silva L.F.P., VandeHaar M.J., Weber Nielsen M.S., Smith G.W., 2002. Evidence for a local effect of leptin in bovine mammary gland. J. Dairy Sci. 85, 3277-3286

Stone R.T., Kappes S.M., Beattie C., 1996. Two polymorphic microsatellites within an $18 \mathrm{~kb}$ genomic clone containing the bovine ob gene. Anim. Genet. 27, Suppl. 2, 64

Zhang F., Basinski M.B., Beals J.M., Briggs S.L., Churgay L.M., Clawson D.K., DiMarchi R.D., Furman T.C., Hale J.E., Hsiung H.M., Schoner B.E., Smith D.P., Zhang X.Y., Wery J.P., Schevitz R.W., 1997. Crystal structure of the obese protein leptin-E100. Nature 387, 206-209

Zhang Y., Proenca R., Maffei M., Barone M., Leopold L., Friedman J.M., 1994. Positional cloning of the mouse obese gene and its human homologue. Nature 372, 425-432 
Zwierzchowski L., Oprządek J., Dymnicki E., Dzierzbicki P., 2001. An association of growth hormone, $\kappa$-casein, $\beta$-lactoglobulin, leptin and Pit-1 loci polymorphism with growth rate and carcass traits in beef cattle. Anim. Sci. Pap. Rep. 19, 65-77

Żarnecki A., Jagusiak W., Czaja H., Trela J., 2003. Sire evaluation for dairy production and type traits (in Polish). Annual Report, National Research Institute of Animal Production (IZ) Kraków, Vol. 24, ISSN 0867-1249

STRESZCZENIE

Wpływ polimorfizmu genu leptyny na wartość hodowlaną dla cech mleczności u bydła

Celem pracy było określenie zależności między polimorfizmem Arg4Cys i Ala59Val bydlęcego genu leptyny a wartością hodowlaną buhajów dla cech mleczności. Analizą objęto 187 osobników. Frekwencje alleli były następujące: 0,55 (C) i 0,45 (T) dla mutacji Arg4Cys oraz 0,73 (C) i 0,27 (T) dla Ala59Val. Genotyp Arg4Cys - TT wysoce istotnie wpływał na podniesienie wydajności mleka i istotnie na zwiększenie wydajności białka. Nie stwierdzono natomiast jego oddziaływania na wydajność tłuszczu, zatem genotyp ten wysoce istotnie obniżał procentową zawartość tłuszczu w mleku. W przeciwieństwie do Arg4Cys, polimorfizm Ala59Val nie wpływał na wydajność mleka i białka, oddziaływał natomiast na zmienność wydajności tłuszczu. 